\title{
Eminent scientists reject the supernatural: a survey of the Fellows of the Royal Society
}

\author{
Michael Stirrat ${ }^{1 *}$ and R Elisabeth Cornwell ${ }^{2}$
}

\begin{abstract}
Fellows of the Royal Society of London were invited to participate in a survey of attitudes toward religion. They were asked about their beliefs in a personal God, the existence of a supernatural entity, consciousness surviving death, and whether religion and science occupy non-overlapping magisteria (NOMA). Overwhelmingly the majority of Fellows affirmed strong opposition to the belief in a personal god, to the existence of a supernatural entity and to survival of death. On 'NOMA', the majority of Fellows indicated neither a strong disagreement nor strong agreement. We also found that while (surprisingly) childhood religious upbringing and age were not significantly related to current attitudes toward religion, scientific discipline played a small but significant influence: biological scientists are even less likely to be religious than physical scientists and were more likely to perceive conflict between science and religion.
\end{abstract}

Keywords: Religion and science; NOMA

\section{Background}

In the USA, while around $16 \%$ of the general population report no religious affiliation approximately $95 \%$ believe in God or some higher power (Gallup \& Lindsay 1999); (Lugo et al 2008). US scientists, however, are substantially less likely to hold belief in the supernatural (Larson and Witham 1997; Leuba 1916). Interestingly, this difference is far more evident among distinguished scientists: Larson and Witham (1998) found that 92\% of the members of the National Academy of Sciences reject a belief in God or higher power. Religiosity in Great Britain is less robust than in the US, with polls reporting only $42 \%$ believing in a personal God and $52 \%$ believing that God or some higher power had a hand in creating the universe (ICM Research 2005). What about British scientists? One thousand and seventy-four Fellows of the Royal Society of London were invited to participate in a survey of attitudes toward religion; 248 Fellows replied. They were asked about their beliefs in a personal God, the existence of a supernatural entity, consciousness surviving death, and whether religion and science occupy non-overlapping magisteria (NOMA). Overwhelmingly, the majority of Fellows affirmed strong opposition to the belief in a personal god, to the existence of a

\footnotetext{
* Correspondence: michael@explainingbehaviour.com

'University of Stirling, Stirling, FK9 4LA, UK

Full list of author information is available at the end of the article
}

supernatural entity, and to consciousness after death. With regard to 'NOMA', there was no consensus among the Fellows as to whether science and religion are in conflict. We also found that while (surprisingly) childhood religious upbringing and age were not significantly related to current attitudes toward religion, scientific discipline played a small but significant influence: biological scientists are even less likely to be religious than physical scientists. This may be because biology currently bears the brunt of religious interference in science: for example, evolution, stem-cell research, and cloning have been targeted recently by religious activists. However, this suggested explanation does not explain the lack of consensus upon whether science and religion can coexist without conflict. To our knowledge, whether scientists perceive conflict with religion has not previously been explored among top scientists and the differences in perceptions reported here between the biological and physical sciences suggest that religious ideas are more in conflict with biology than other sciences.

\section{Methods}

All Fellows of the Royal Society with an active e-mail address (the great majority of them: $n=1,074$ ) were sent a request to complete a brief survey on religious attitudes. If they wished to participate in the survey, 


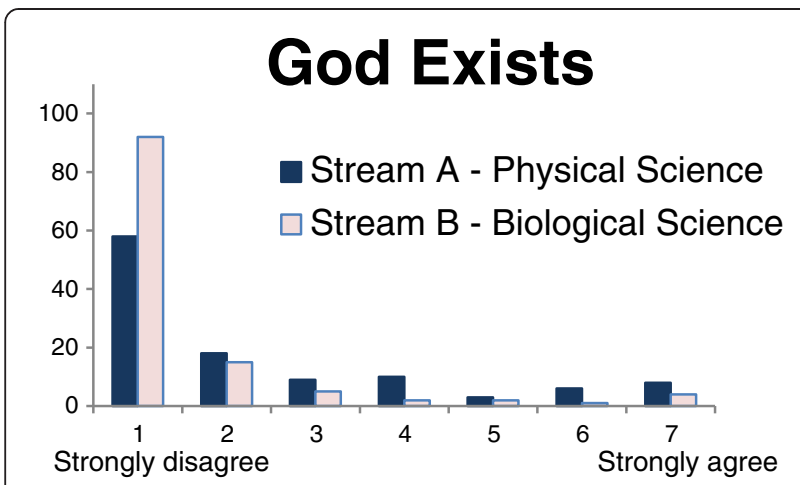

Figure 1 I believe that there is a strong likelihood that a supernatural being such as God exists or has existed.

they were invited to connect through a link to our website. The site itself remained open for 14 days, after which access to the survey was denied.

We invited Fellows to indicate their level of agreement/ disagreement with four statements concerning religious attitudes:

1. I believe that there is a strong likelihood that a supernatural being such as God exists or has existed.

2. I believe in a personal God, that is one who takes interests in individuals, hears and answers prayers, is concerned with sin and transgressions, and passes judgment.

3. I believe that science and religion occupy non-overlapping domains of discourse and can peacefully co-exist (NOMA).

4. I believe that when we physically die, our subjective consciousness, or some part of it, survives.

(Participants were asked to indicate their level of agreement on a 7-point Likert-type scale, with 7 = strongly agree and 1 = strongly disagree).

Other questions included sex, age, field of science (biological or physical), place of birth, religious upbringing,

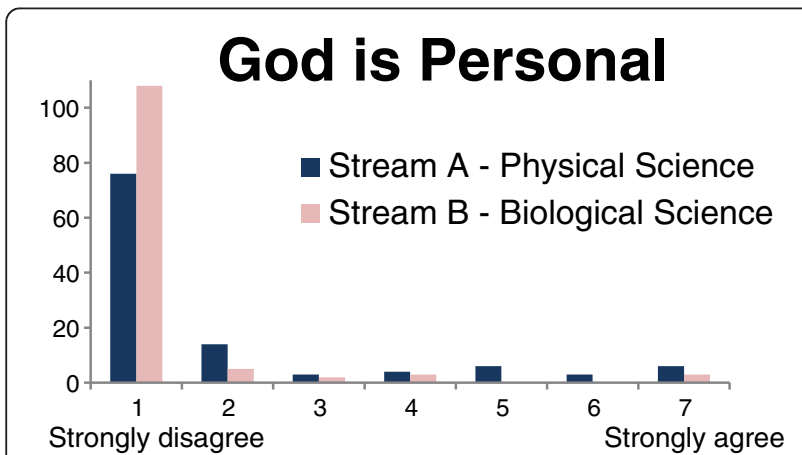

Figure 2 I believe in a personal God, that is one who takes interests in individuals, hears and answers prayers, is concerned with sin and transgressions, and passes judgment.

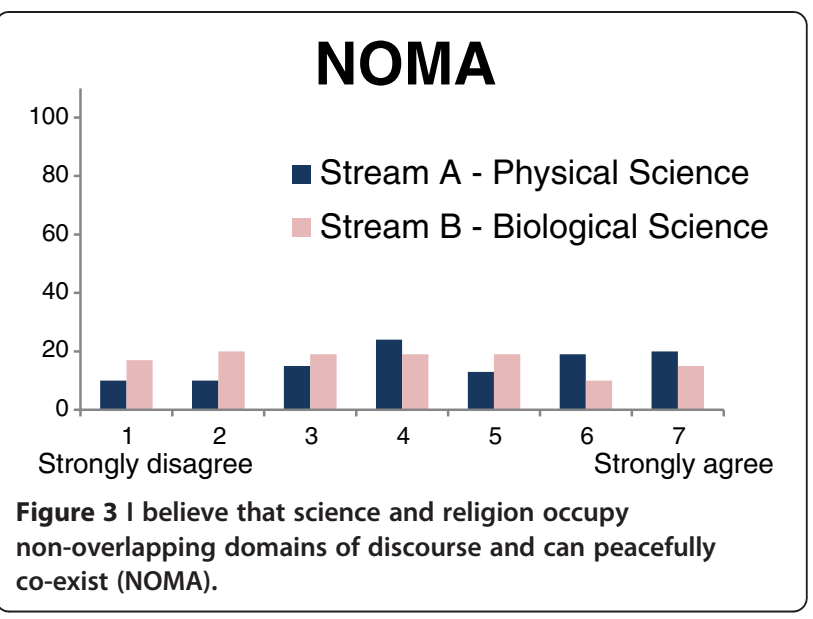

and current religious affiliation. We also solicited free comment on the poll.

\section{Results}

We received completed surveys from 248 Fellows (9 women, 239 men: $95.3 \%$ of the 1,316 Fellows are men) with an age range of 42 to 88 years (mean $=64.5$ years, $\mathrm{SD}=9.59$ ). Fellows are normally recognized for a substantial body of scientific work, which makes election before the age of 40 years unlikely. Of those who responded, 113 were from the physical sciences (for example, physics, astronomy, chemistry, computer sciences, mathematics, $45.6 \%$ ) and 122 from the biological sciences (for example, zoology, botany, human sciences, medicine, 49.2\%). Data were missing for 13 Fellows (5.2\%). One-sample T-test revealed no significant difference between physical and biological scientists in response rate, $P=0.607$.

Childhood religious upbringing was mainly Anglican (107: 43.1\%), followed by agnostics/atheists/no religion (52: $21.0 \%$ ), other Christian (42: 16.9\%), Roman Catholic (19: 7.7\%), Jewish (14: 5.6\%), Hindu/Muslim/Sikh (3: 1.2\%), and other (2: $0.8 \%$ ), with some not reporting (9: 3.6\% missing data). Professed current religious affiliation reflected a large shift towards non-belief led by agnostics/

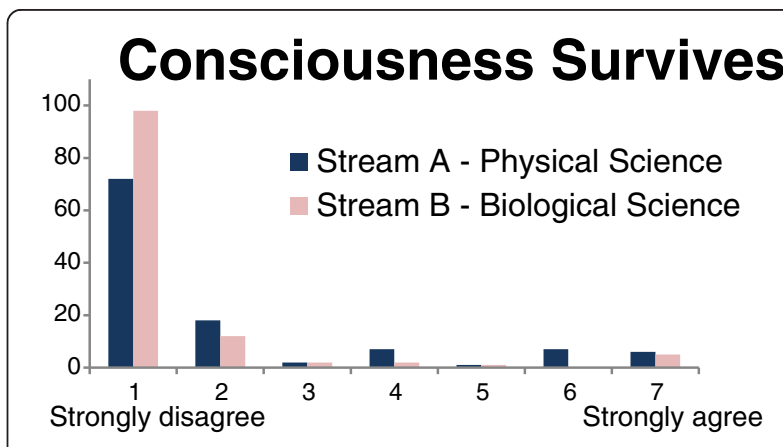

Figure 4 I believe that when we physically die, our subjective consciousness, or some part of it, survives. 
atheists/none (198: 79.5\%), Anglican (24: 9.7\%), other Christian (11: 4.4\%), Jewish (5: 2.0\%), and Roman Catholic (4: $1.6 \%)$, with some missing data (6: $2.4 \%)$.

For our religious attitudes questions, we received 246 responses for all but the NOMA question, for which we received 243 responses. The responses are presented in Table 1.

Overall, the majority of Fellows indicated lack of belief in God (Table 1), with 78.0\% strongly disagreeing (answer 1 or 2) and only 8.1\% strongly agreeing (answer 6 or 7). Disbelief in a personal God was even stronger; $86.6 \%$ strongly disagreed (answer 1 or 2 ) and $5.3 \%$ strongly agreed (answer 6 or 7). Belief in consciousness surviving death was reported at a similar level; $85.0 \%$ strongly disagreed (answer 1 or 2 ) and $8.1 \%$ strongly agreed (answer 6 or 7).

The NOMA question gave us our most varied and somewhat surprising response. There was a nearly uniform response over all seven levels of agreement or disagreement, with a very small plurality agreeing that religion and science can peacefully co-exist (28.4\% versus $24.3 \%)$ although when the data were split by whether the Fellows belonged to the biological or physical sciences there were different results (see Table 2). Fellows from the physical sciences tended to see less conflict between science and religion (31.5\% agreed versus 18.0\% disagreed) and Fellows from the biological sciences tended to see more (21.0\% agreed versus $31.1 \%$ disagreed).

\section{Childhood religion}

We examined whether or not religious upbringing played a role in current attitudes toward religion. ANOVAs indicated that there were no differences between our groups based on childhood religious affiliation for three of our four questions: belief in the existence of a supernatural being, belief in a personal God, and NOMA (all $P \geq 0.187$ ). With regard to whether consciousness might survive death, a couple of outliers (a very small number of Hindu and Sikh responders) created a significant result $F(10,233)=3.203, P=0.001$, but if these were excluded childhood religious influences on the question of immortality are non-significant $(P=0.308)$.

\section{Linear regression}

To examine whether or not age and field of science (physical or biological coded as $0-1$ variable) contributed to our results, we ran a linear regression analysis. We found significant effects for all four of our questions, with field of science, but not age, predicting responses. Biological scientists were significantly more likely to disagree with all four statements (see Table 2). That is, biological scientists were even less religious than physical scientists, and less likely to accept that science and religion can peacefully co-exist. For our question on whether or not a supernatural being exists, we found field of science $(\beta=-0.281)$ predicted belief (see Figure 1 ), the model accounting for $8.1 \%$ of the variance $\mathrm{R}^{2}=0.081$ (adjusted $\mathrm{R}^{2}=0.072$ ), $\mathrm{F}(2,224)=9.818, P<0.001$ (age, $\beta=$ $-0.110)$. Field of science $(\beta=-0.257)$ was also found to be the strongest predictor for our question on belief in a personal God (Figure 2), accounting for $6.9 \%$ of the variance $R^{2}=0.069$ (adjusted $\left.R^{2}=0.061\right), F(2,224)=$ 8.311, $P<0.001$ (age, $\beta=-0.107$ ). This effect was also found on the question of immortality (Figure 4): field of science $(\beta=-0.212)$ again being the strongest predictor and accounting for $6.2 \%$ of the variance $R^{2}=0.062(\mathrm{ad}-$ justed $R^{2}=0.053$ ), $F(2,224)=7.372, P=0.001$ (age, $\beta=$ -0.169 ). For the NOMA question, however, regression analysis indicated that field of science and age accounted for only $3.9 \%$ of the variance $\mathrm{R}^{2}=0.039$ (adjusted $\left.R^{2}=0.030\right), F(2,220)=4.437, P=0.013$ (field, $\beta=$ -0.192 ; age, $\beta=-0.083$ ) see (Figure 3 ).

\section{Discussion}

In line with the Leuba (1916) and the Larson and Witham (1998) findings for the United States, eminent scientists in Britain and the Commonwealth reject belief in a personal God, the existence of a supernatural being, and consciousness surviving death. Given that our sample is drawn from a far less religious population than the US, we also expected that our results would be more extreme than in the US and this was confirmed (for example, in our sample $5.3 \%$ believe in a personal God and $86.6 \%$ do not believe compared with Larson and Witham's US results of 7.0\% and 72.2\%, respectively).

Table 1 Number of responses to each question

\begin{tabular}{|c|c|c|c|c|c|}
\hline & Scale & God exists & God is personal & NOMA & Consciousness survives \\
\hline \multirow[t]{6}{*}{ Strongly disagree } & 1 & 157 & 193 & 29 & 178 \\
\hline & 2 & 35 & 20 & 30 & 31 \\
\hline & 3 & 16 & 6 & 36 & 5 \\
\hline & 4 & 13 & 8 & 44 & 10 \\
\hline & 5 & 5 & 6 & 35 & 2 \\
\hline & 6 & 8 & 4 & 31 & 9 \\
\hline Strongly agree & 7 & 12 & 9 & 38 & 11 \\
\hline
\end{tabular}


Table 2 Responses split by field of study

\begin{tabular}{|c|c|c|c|c|c|c|c|c|c|}
\hline \multirow{2}{*}{\multicolumn{2}{|c|}{ A = Physical; B = Biological }} & \multicolumn{2}{|c|}{ God exists } & \multicolumn{2}{|c|}{ God is personal } & \multicolumn{2}{|c|}{ NOMA } & \multicolumn{2}{|c|}{ Consciousness survives } \\
\hline & & \multirow{2}{*}{$\begin{array}{l}\text { A } \\
57\end{array}$} & \multirow{2}{*}{$\begin{array}{l}\text { B } \\
93\end{array}$} & \multirow{2}{*}{$\begin{array}{l} \\
76\end{array}$} & \multirow{2}{*}{$\begin{array}{l}\text { B } \\
109\end{array}$} & \multirow{2}{*}{$\begin{array}{l}\text { A } \\
10\end{array}$} & \multirow{2}{*}{$\begin{array}{l}\text { B } \\
17\end{array}$} & \multirow{2}{*}{$\begin{array}{l}\mathbf{A} \\
71\end{array}$} & \multirow{2}{*}{$\begin{array}{l}\text { B } \\
99\end{array}$} \\
\hline Strongly disagree & 1 & & & & & & & & \\
\hline & 2 & 19 & 15 & 14 & 5 & 10 & 20 & 19 & 12 \\
\hline & 3 & 9 & 5 & 3 & 2 & 14 & 19 & 2 & 2 \\
\hline & 4 & 10 & 2 & 4 & 3 & 24 & 20 & 7 & 2 \\
\hline & 5 & 3 & 2 & 6 & 0 & 13 & 19 & 1 & 1 \\
\hline & 6 & 6 & 1 & 3 & 0 & 19 & 10 & 7 & 0 \\
\hline \multirow[t]{4}{*}{ Strongly agree } & 7 & 8 & 4 & 6 & 3 & 20 & 15 & 6 & 5 \\
\hline & $\mathrm{N}$ & 112 & 122 & 112 & 122 & 110 & 120 & 113 & 121 \\
\hline & Mean & 2.400 & 1.560 & 1.960 & 1.300 & 4.430 & 3.780 & 2.050 & 1.460 \\
\hline & Standard error & 0.182 & 0.121 & 0.167 & 0.096 & 0.181 & 0.176 & 0.171 & 0.120 \\
\hline
\end{tabular}

However, our overall findings are not surprising, as other studies have found that scientists, especially preeminent scientists, tend toward disbelief (Larson and Witham 1997, 1998; Leuba and Kantor 1917; Leuba 1916). While we have ideas as to why this trend exists, our data from this short survey do not allow us to do much more than speculate.

Previous research has also shown that biologists and psychologists are the most atheistic of scientists (for example, Gross and Simmons 2009) and we were therefore not overly surprised to find that in our sample the biological scientists were more atheistic with regard to a belief in God and life after death than the physical scientists. The relationship between field of science and attitude to the question of whether religion and science are in conflict is, perhaps, more difficult to understand.

The surprising results of the NOMA question have, to our knowledge, not previously been explored among top scientists. The Fellows' responses to the NOMA question fall across the spectrum from overt conflict to peaceful co-existence. Since an answer of ' 7 ' indicates no tension between religion and science and an answer of ' 1 ' overt conflict, we get a picture that most Fellows believe that tensions do indeed exist between these two ways of examining the world, while disagreeing (or individually unsure) about the extent of that tension. What is clear, therefore, is that the majority of these predominately atheistic scientists see tensions but do not see religion as in overt conflict with science.

Complicating this picture is the fact that alongside a greater likelihood of expressing atheistic views the biological scientists in our sample were also less likely than physical scientists to accept that science and religion can peacefully co-exist. This may be because the biological sciences bear the brunt of religious interference in science. For example, evolution, stem-cell research, and cloning have been targeted, albeit in varying degrees and from different directions, by religious activists. Also, there is evidence that evolutionary thinking itself may shift scientists away from God-belief (Dias et al. 2012; Leigh 2013). On the other hand, not since the time of Galileo have the physical sciences been threatened by religious dogma. It may be therefore that scientists' attitudes to religious beliefs are shaped by the experience of direct antagonism (or lack of it) toward their science.

\section{Conclusion}

We set out to investigate whether or not preeminent British scientists share their American colleagues' rejection of supernatural religion and found that they do. There are still many questions worth pursuing, not least the question of why biological scientists are even less likely to be religious than physical scientists.

Whether we personally hold religious beliefs or not, it is important we understand the perceptions of scientists with regard to religion and how these differ in line with scientific ideas given that scientists hold so much sway in the marketplace of ideas.

\section{Competing interests}

The authors declare that they have no competing interests.

\section{Authors' contributions}

REC is responsible for initial conception of the study and contact with the FRS. MS provided questionnaires and online protocols for data collection. Both authors were equally responsible for analysis and interpretation of results as well as drafting the manuscript. Both authors read and approved the final manuscript.

\section{Author details}

${ }^{1}$ University of Stirling, Stirling, FK9 4LA, UK. ${ }^{2}$ Trinity College, 300 Summit Street, Hartford CT 06106.

Received: 5 July 2013 Accepted: 18 November 2013 Published: 09 Dec 2013

\section{References}

Dias, IA, Willemart, RH, \& Marques, AC. (2012). Does evolution matter? A case study in Brazil of the effects of an evolutionary-thinking academic atmosphere in postgraduate students' belief in God/religious belief. Anais da Academia Brasileira de Ciencias, 84(2), 551-554. 
Gallup, G., \& Lindsay, D. M. (1999). Surveying the religious landscape: Trends in US beliefs. Morehouse Pub

Gross, N, \& Simmons, S. (2009). The religiosity of American college and university professors. Sociology of Religion, 70(2), 101-129.

ICM Research. (2005). BBC religion survey. BBC. http://www.icmresearch.com/bbcreligion-survey-07-07-05

Larson, EJ, \& Witham, L. (1997). Scientists are still keeping the faith. Nature, 386(6624), 435-436.

Larson, EJ, \& Witham, L. (1998). Leading scientists still reject God. Nature, 394(6691), 313-314.

Leigh, EG. (2013). Does evolution compromise Christian faith? R. J. Asher's evolution and belief. Evolution: Education and Outreach, 6(1), 15.

Leuba, JH. (1916). The belief in God and immortality: a psychological, anthropological and statistical study. Boston, MA: Sherman, French \& Co.

Leuba, JH, \& Kantor, JR. (1917). Statistics of belief in God and immortality. International Journal of Ethics, 28, 109-114.

Lugo, L., Stencel, S., Green, J., Smith, G., Cox, D., Pond, A., Miller, T., Podrebarac, E., Ralston, M., Kohut, A., Taylor, P., Keeter, S. (2008). U.S. Religious Landscape Survey: Religious Affiliation - Diverse and Dynamic, The Pew Forum on Religion \& Public Life. Washington, D.C. Pew Research Center.

10.1186/1936-6434-6-33

Cite this article as: Stirrat and Cornwell: Eminent scientists reject the supernatural: a survey of the Fellows of the Royal Society. Evolution: Education and Outreach 2013, 6:33

\section{Submit your manuscript to a SpringerOpen ${ }^{\circ}$ journal and benefit from:}

- Convenient online submission

- Rigorous peer review

- Immediate publication on acceptance

- Open access: articles freely available online

- High visibility within the field

- Retaining the copyright to your article

Submit your next manuscript at $\gg$ springeropen.com 